\title{
Chapter 4 \\ Introduction to Section I: Sign Systems and Medial Transformations*
}

\author{
Jörg Wesche
}

\subsection{Translation in the Limelight: Processes and Projections}

\footnotetext{
'Tis written: "In the beginning was the Word!"

Here now I'm balked! Who'll put me in accord?

It is impossible, the Word so high to prize,

I must translate it otherwise

If I am rightly by the Spirit taught. ${ }^{1}$
}

Faust's struggle to find an adequate German translation of the term "logos" appearing at the beginning of the Gospel of John is presumably the most wellknown example of a translation scene in world literature. In the study room episode, Goethe presents the Early Modern scholar as a bible translator who departs from the literal translation of verbally inspired speech and, considering the alternatives "word", "thought", and "power", ultimately decides on "deed" as the best analogous translation.

The scene thus strikingly visualizes the fundamental nature of translation as a word-finding process. Far from spontaneous interpretation, what characterizes

${ }^{1}$ Goethe (1958), p. 30.

*Translated by Judith Rosenthal

J. Wesche $(\square)$

Georg-August-Universität Göttingen, Göttingen, Germany

E-Mail: joerg.wesche@uni-goettingen.de 
writing-based translation is reflective deliberation of the stock of signs available in the source and target languages. The translation process thus appears to be a search for the best signs, and one that, from the perspective of translation studies, can be described in terms of the equivalence theory. Seen from this perspective, it presupposes reciprocal translatability, while also being expected to satisfy standards of denotative, connotative, text-normative, pragmatic, and formalaesthetic equivalence. ${ }^{2}$

The translation scene from Faust can serve as an instructive point of departure for the introduction to the first section of this volume, because it not only reflects on the translation process itself, but at the same time also transforms that process into a different medium: the dramatic context of a stage play. Naturally, Goethe elaborated on the painstaking preoccupation in a theatrically clever manner. For one thing, in the play's dramaturgical development, Faust's monologic musings on the Word of God serve not least of all to provoke the poodle that has been skulking about his study room and shortly thereafter, as we know, will come out from behind the stove as Mephistopheles in the guise of a wandering scholar. And even if this does not lead the genius Faust to fling his inkwell, he bears a distinct similarity to the bible translator Luther, who was likewise in the habit of translating not word-for-word, but programmatically sense-for-sense. What is more, by citing John 1:1 at the beginning of the scene, Goethe further accentuates the family resemblance by demonstrating the principle of sense-for-sense translation on the word for "word" ("logos"), of all words.

At the same time, Goethe's staging of the translation act represents both a fictional and a historical projection - in other words, an image of the Early Modern period. And that is the case even if he still conceived of the sixteenth century as an intermediate period between antiquity and modernity "in the sense of the Middle Ages". This is evident, for example, in the famous stage direction at the beginning of the laboratory scene in Faust, Part Two. ${ }^{3}$ This historical projection is justified even from the present-day point of view, and in a twofold sense. For one thing, it casts Faust's epoch in a translation scene. This basic idea is ultimately consistent with the priority programme SPP 2130, which has set out to delineate the Early Modern period as it is manifest in translation cultures. For another thing, Goethe's projection also marks the historical distance between the audience and the theatrical action, thus calling attention to the projective character of historical fiction itself. If we think through the translation scene historiographically, the dramatic projection can also serve as a reference to the history of Early Modern translation as an unknown. How are we to imagine the process of translation in the Early Modern period - similar to how Goethe visualized it, and if not, how else, and if so, what is still missing from the picture? These queries are still relevant today. Because however intensive the research, for

\footnotetext{
${ }^{2}$ For a fundamental discussion of the types of equivalence mentioned here, see Koller (1992). ${ }^{3}$ Goethe (1958), p. 167.
} 
example on the Early Modern translation of the classics, ${ }^{4}$ the period in question is still largely uncharted as an era of dynamic translation cultures. This is also true of the field contemplated by Goethe - that of Early Modern Bible translation ${ }^{5}$ - even if research on the translation history of the world's most frequently translated book is unparalleled in magnitude. ${ }^{6}$

\subsection{Early Modern Translation: Practices and Reflections}

Against the above-sketched backdrop, the first section of this collective volume is concerned with the foundation of Early Modern translation culture, namely translation itself. How was translation theoretically reflected on as a process in the relevant historical settings; how was it practised in the existing semiotic systems and how, as the case may be, was it medially transformed?

With a view to the translation-scholarly differentiation between intralingual, interlingual, and intersemiotic translation, ${ }^{7}$ section one begins with a focus on interlingual translation. Historical conceptualizations of translation processes themselves are the basis for describing and understanding Early Modern translation cultures. Often found only sporadically or scattered among paratexts to individual translations, such conceptualizations have yet to undergo systematic review, even for the European vernaculars.

German Baroque poetry is a telling illustration of the tremendous role played by interlingual translation praxis in the seventeenth century. With regard to norms and the integration of foreign language models, this school of poetry was based primarily on strategic translation achievements that, in view of the profound imprint of linguistic patriotism on Baroque poetry, were long perceived with a narrow focus on the classical canon, if at all. The example par excellence is the Silesian poetry reformer Martin Opitz, who is unrivalled in the formative influence he exerted on German seventeenth-century poetry. It is by no means solely his Buch von der Deutschen Poeterey published in 1624 that accounts for the potency of his reform efforts, but also and above all his prolific activities as a translator, which had a stimulating impact on the rapid development of ever more nuanced differentiation and the reproduction of foreign-language patterns in the German poetry of the time. Opitz is thus not only considered the "father

\footnotetext{
${ }^{4}$ See, for example, recently Toepfer et al. (2017).

${ }^{5}$ Especially worthy of mention in this context is the long-term interacademic project on the late medieval "Austrian Bible Translator" (see https://bibeluebersetzer.badw.de/en/the-project.html [accessed 11 September 2020]).

${ }^{6}$ Among the more recent works, see, for example, Kuschmierz and Kuschmierz (2007) and Müller and Heyden (2020).
}

${ }^{7}$ Jakobson (1987), p. 233. 
of German poetry"8 until Gottsched, but also - as Justus Georg Schottel sums it up it in his grammar - as a "master of the art of interpretation". "What is more, his art is by no means based one-sidedly on the - in part deceptive ${ }^{10}$ - translation of the classics. ${ }^{11}$ On the contrary, it is founded to a large extent on the translation of Romance and Netherlandish patterns ${ }^{12}$ that, in Opitz's oeuvre, lay the foundation not only for a new German poetics but also for the poetics of the period in general. ${ }^{13}$ German poetry of the seventeenth century accordingly emancipated itself increasingly from the late humanist classical canon and developed in the direction of the pluralization of authority ${ }^{14}$ and internationalization. ${ }^{15}$ If we were to pose the question as to the scope orientation of this broad-based translation praxis, we would receive a contemporary answer from, among others, Georg Philipp Harsdörffer. The latter visualized cultural-dynamic reception, translation, and appropriation as a process of ennoblement, and compared the literary activity with the tailor's craft, where "the apprentices make dresses from their masters' coats, trimming them so splendidly with silver and gold that they are no longer recognizable". He accordingly considered a poetry translation well-wrought "if it is so pleasant-sounding that one does not even notice its having originally been written in a different language". ${ }^{16}$ In Harsdörffer's view, the ideal of translation was thus not alterity and its preservation but identity.

It is precisely the Early Modern period's universal conception of translation that also permits a look at the basic forms of intralingual and intersemiotic translation. The experience and interpretation of the world in the Early Modern period were shaped to a decisive degree by semiotic thought models implying acts of translation. Within this context, the conceptions of a universal 'sign cosmos' drew from a wide range of different sources.

On the one hand, the allegorical conception of the world that had prevailed in the Middle Ages was still potent. In keeping with the Augustinian tradition, material things were regarded as carriers of higher meaning. Theologians and natural historians thus faced the hermeneutic task of deciphering the language of things, and of translating - and, in the second meaning of the Latin interpres, interpreting - the perceivable into meaning. In the context of linguistic mysticism and natural language, the res were assigned a status comparable to that of iconic

\footnotetext{
${ }^{8}$ See Garber (1976). [Trans. JR].

${ }^{9}$ Schottel (1663), p. 1222. [Trans. JR].

${ }^{10}$ While pretending to translate entirely from the Latin, Opitz also made use of phrases from a German text. See Wesche (2017).

${ }^{11}$ On this subject, see above all Alewyn (1962) and Woesler (2012).

${ }^{12}$ See, among others, Gülich (1972); Pott (1957); Wesche (2018).

${ }^{13}$ See, for example, Zymner (2002).

${ }^{14}$ Robert (2004).

${ }^{15}$ Wesche (2021).

${ }^{16}$ Harsdörffer (1650), pp. 102-103. [Trans. JR].
} 
signs. ${ }^{17}$ In the area of poetry, for example, the verba were subject to the Horatian ut pictura poesis formula, leading to the assumption of the exchangeability of pen and brush and thus, in the historical conception, also that between the arts. ${ }^{18}$ Like the liber naturae, books written by humans also contained hidden messages. The integumentum doctrine, whose most well-known medieval exponent was Peter Abelard, called upon recipients to reveal the truths concealed in classical literature and philosophy. Allegorical interpretation retained its importance in the Early Modern period, a circumstance to which the numerous allegorical dictionaries published in the sixteenth and seventeenth centuries bear ample testimony.

On the other hand, the rediscovery of Platonic philosophy, the interest in the kabbala, and the Paracelsian doctrine of signatures added fuel to the "metaphorically interpretive thought"19 characteristic of architecture, sculpture, painting, and literature. Hieroglyphs, for instance, were regarded as visual symbols pointing directly to the truth. ${ }^{20}$ As a mundus significativus, creation in its entirety - whether the work of God or man - was conceded a semiotic-spiritual dimension; natural and cultural signs alike were to be read and interpreted - that is, translated - to decipher their meaning.

In view of these findings, the first section also sets its sights on the study of intersemiotic translations, which can be investigated, for example, in the form of text-image relationships. Finally, the third - intralingual - form of translation, is manifest primarily in the Early Modern reception of medieval literature.

\subsection{The Project Spectrum: Fields of Investigation and Results}

For the reconstruction of the historical conceptualizations and practices of translation, the first section offers a foundational research platform for reflection on different sign systems and their use. Of key importance here is the relationship between semiotic encoding and medial communication. How do the sign process and mediality interact in translations, and how are the specific translation objects transformed by their respective medial frameworks? Section one offers research perspectives on the links between translation and Early Modern reflection on language, translation and language work, the history of semiotics, and the history of media.

With a focus on the Welsh (Bible) translation culture of the sixteenth century, the first contribution, by Elena Parina and Erich Poppe (see chap. 5), sets out to

\footnotetext{
${ }^{17}$ See Plotke (2009), pp. 80-86.

${ }^{18}$ See Plotke (2009), pp. 120-121.

${ }^{19}$ Trunz (1957), pp. 11-13. [Trans. JR].

${ }^{20}$ Gindhart (2017).
} 
reconstruct strategies for translation into Cymric as exemplified by religious texts. As a study on interlingual translation, it provides access to an obscure historical sign system. More specifically, what Parina and Poppe offer is a case study on the use of loanwords and the handling of Bible quotations in the translation praxis of Robert Gwyn, which on the whole was strongly counter-Reformational in character. The authors moreover show how the religious orientation of the translation prompts Gwyn to engage in translation-theoretical reflection (for example with regard to the problem of verbal inspiration on the one hand and ambiguity in the translation of the Bible on the other). Notably, the analysis provides evidence of the translator's firm intention to subordinate the translation activity consistently to the task of instructing an unlearned (Welsh) readership and congregation in order to achieve a broad impact in the target language. To shed light on the specific nature of Gwyn's translation praxis, the contribution cites strikingly contrastive comparisons to practices of scholarship-oriented, reform, and ironically oriented translation of the sixteenth and seventeenth centuries, thus achieving substantial translation-historical scope and applicability.

Striking a fine balance between the fields of literary studies and musicology, the contribution by Astrid Dröse and Sara Springfield examines an intersemiotic constellation: the song culture of the seventeenth century as a translation culture (see chap. 6). As a kind of historical expansion of the art zone into the so-called interart studies, it tests methods and perspectives of an interdisciplinary research field, citing above all the example of the Baroque song composer Heinrich Albert, a member of the Königsberg Kürbishütte circle. Albert's Arias constitute one of the most important bodies of seventeenth-century German song literature, which are based largely on European - and especially Italian and French - song culture. What we have here is thus not only a specifically bimedial constellation, but also a case of literary comparison. To analyze the song translations, the authors differentiate between individual and systemic translational references while also applying a comprehensive heuristic model that keeps sight of both the specific mediality and the various sociocultural contexts - the 'real-life settings' - of the different song translations. This approach allows them to retrace how Albert's translation transformed, for example, the courtly lied form of the French "air de cour" into the bourgeois social context of the Königsberg Kürbishütte both poetically and medially.

The contribution by Irina Saladin (see chap.7), analyzing the cartography of North America by Claude and Guillaume Delisle, is likewise a study in intersemiotics but adopts a perspective very different from Dröse and Springfield's comparison of the arts. Saladin poses the question of how the two famous French "armchair geographers" (géographes de cabinet) translated historical textual testimonies such as travel reports, historical treatises, and letters as well as oral information from travellers into maps. She begins with an in-depth reflection on methods of intermedial translation, heuristically taking approaches to narratologically oriented cartographic history into consideration in the process. Citing the Delisles' maps of North America by way of example, she then goes on to examine the underlying contexts (for instance the Delisles' life circumstances, 
their workshops, source materials, and networks, etc.) and, against that background, focusses on the medial transformation resulting from the gradual translation of the texts into maps. She thus succeeds in showing how the linear, and in part narrative, quality of the textual testimonies used by the Delisles came to bear as knowledge of routes in the intermediate medial shift from text to sketch and from there to the final product, the graticule-based map.

With a look at the spectrum of actors and sources in neoclassicist France, the contribution by Andreas Gipper and Diego Stefanelli (see chap. 8) extends the period under investigation to the eighteenth century. Based on the example of the translational triangle Bonnet-Spallanzani-Senebier, the study outlines the phenomenon of scientific translation as a generator of symbolic capital. The object of attention is thus once again an interlingual situation encompassing the translation of scientific texts both from French into Italian (Bonnet/Spallanzani) and Italian into French (Spallanzani/Senebier). On the basis of their analysis, Gipper and Stefanelli show that, in the period in question, the collaboration of translators with scientists - in the context of the natural sciences on the one hand and the ascent of European vernaculars as scientific languages on the other hand - defies one-dimensional description of the translator as an invisible 'service provider'. On the contrary, the boundaries are fluid: natural scientists such as Spallanzani were among both the translators and the translated. In the case of the particular triumvirate chosen by the authors, the source material permits a Bourdieu-oriented sociological reconstruction of the translators' respective motives in terms of both scientific and language politics. Strategically speaking, for example, already the mere fact of being translated could mean symbolic capital profit maximization, expansion of prestige, or a recognized place as an independent natural scientist in the respective scientific field. What is more, against the backlight of its competition with Italian, the (relay) function of French in European translation culture takes on clear contours: it was in the eighteenth century that French set out to become a universal scientific language.

Section one closes with the contribution by Hans-Jürgen Lüsebrink on translations in French encyclopaedias as exemplified by the Encyclopédie Méthodique and Diderot's and D'Alembert's Encyclopédie - and thus with a further inquiry into interlingual translation (see chap.9). By concentrating on translation from and into key French (and European) encyclopaedias of the eighteenth and early nineteenth centuries, however, it broadens the section's methodological spectrum by taking a metatextual level of the historical translation discourse into account. In the encyclopaedias selected for this study, the subject of translation itself proves especially productive, because here the concern is with analyzing the extensive historical descriptions in the articles on translation, translator, version, inversion, etc. Owing to the fact that - in keeping with requirements of encyclopaedic texts - these entries reflect the contemporary state of knowledge to the greatest possible degree, the contribution represents important foundational research for the reconstruction of the European translation culture of the Early Modern period. The special significance of the encyclopaedic discourse for questions of both the praxis and theory of translation in the period in 
question results not only from the compilation of sources and outlooks considered important with regard to translation history, but also from the temporal origination of these particular encyclopaedias in the middle of the French Revolution - that is, at the cusp between the Early Modern and the Modern ages. Not the least important attribute of this study is that it thus introduces an early retrospection on the translation cultures of the Early Modern period, or, more specifically, of the Enlightenment.

\section{References}

Alewyn, Richard. 1962. Vorbarocker Klassizismus und griechische Tragödie Analyse der „Antigone“-Übersetzung des Martin Opitz. Sonderausgabe. Darmstadt: Wissenschaftliche Buchgesellschaft.

Garber, Klaus. 1976. Martin Opitz - „,der Vater der deutschen Dichtung “. Eine kritische Studie zur Wissenschaftsgeschichte. Stuttgart: Metzler.

Gindhart, Marion. 2017. Bildschrift im Kontext. Die Hieroglyphika-Übersetzung Johannes Herolds (Basel 1554). In Humanistische Antikenübersetzung und frühneuzeitliche Poetik in Deutschland (1450-1620), eds. Regina Toepfer, Klaus Kipf, and Jörg Robert, 243-287. Berlin: de Gruyter.

Goethe, Johann Wolfgang. 1993. Goethes Werke. Hamburger Ausgabe in 14 Bänden. Part III. Dramatische Dichtungen. Textkritisch durchges. und kommentiert von Erich Trunz, Vol. 1, 15 ed. München: Beck.

Goethe, Johann Wolfgang. (1958). Goethe's Faust. Parts one and two. Trans. by George Madison Priest. Chicago: Encyclopaedia Britannica.

Gülich, Anne. 1972. Opitz' Übersetzungen aus dem Französischen. Kiel: Diss. masch.

Harsdörffer, Georg Philipp. 1650. Poetischer Trichter. Die Teutsche Dicht- und Reimkunst/ohne Behuf der Lateinischen Sprache/in VI. Stunden einzugiessen, Vol. 1, 2 ed. Nürnberg: Endter.

Jakobson, Roman. 1987. On linguistic aspects of translation. In Language in literature, eds. Krystyna Pomorska and Stephen Rudy, 428-435. Cambridge: Harvard University Press.

Koller, Werner. 1992. Einführung in die Übersetzungswissenschaft. Heidelberg: Quelle und Meyer.

Kuschmierz, Rainer, and Monika Kuschmierz, eds. 2007. Handbuch Bibelübersetzungen. Wuppertal: Brockhaus.

Müller, Andreas, and Katharina Heyden, eds. 2020. Bibelübersetzungen in der Geschichte des Christentums. Leipzig: Evangelische Verlagsanstalt.

Plotke, Seraina. 2009. Gereimte Bilder. Visuelle Poesie im 17. Jahrhundert. München: Fink.

Pott, Clarence K. 1957. Martin Opitz' Translation from the Dutch. Kentucky Foreign Language Quarterly 4:91-97.

Robert, Jörg. 2004. Martin Opitz und die Konstitution der Deutschen Poetik. Norm, Tradition und Kontinuität zwischen „Aristarch“ und „Buch von der Deutschen Poeterey“. Euphorion 98 (3): 281-322.

Schottel, Justus Georg. 1663. Ausführliche Arbeit von der Teutschen Hauptsprache. Braunschweig: Zillinger.

Toepfer, Regina, Klaus Kipf, and Jörg Robert, eds. 2017. Humanistische Antikenübersetzung und frühneuzeitliche Poetik in Deutschland (1450-1620). Berlin: de Gruyter.

Trunz, Erich. 1957. Weltbild und Dichtung im deutschen Barock. In Aus der Welt des Barock, eds. Richard Alewyn and Wilhelm Boeck, 1-35. Stuttgart: J. B. Metzler. 
Wesche, Jörg. 2017. Trügerische Antikenübersetzung. Poetologisches Translationsverständnis bei Martin Opitz und humanistische Autorisierung im „Lob des Feldtlebens“ (1623). In Humanistische Antikenübersetzung und frühneuzeitliche Poetik in Deutschland (1450-1620), eds. Regina Toepfer, Klaus Kipf, and Jörg Robert, 409-426. Berlin: de Gruyter.

Wesche, Jörg. 2018. Barocke Lautstärke. Oder: Wie Ausdrucksdynamik, Versakustik und deutsch-niederländischer Kulturtransfer zusammenhängen. In Zwischen Sprachen en culturen. Wechselbeziehungen im niederländischen, deutschen und afrikaansen Sprachgebiet, eds. Ute K. Boonen, Bernhard Fisseni, Jörg Wesche, Gaby Boorsma, and Tina Konrad, 241251. Münster: Waxmann.

Wesche, Jörg. 2021. Barockpoetik und Übersetzung. Antwortversuch. In Ästhetische Lektüren Lektüren des Ästhetischen. For Werner Jung, eds. Rolf Parr and Liane Schüller. Bielefeld: Aisthesis.

Woesler, Winfried. 2012. Opitz' Übersetzung von Senecas Troades. In Die Bedeutung der Rezeptionsliteratur für Bildung und Kultur der Frühen Neuzeit (1400-1750), Bd. 1: Beiträge zur ersten Arbeitstagung in Eisenstadt (März 2011), eds. Alfred Noe and Hans-Gert Roloff. Bern: Lang

Zymner, Rüdiger. 2002. Übersetzung und Sprachwechsel bei Martin Opitz. In Martin Opitz (1597-1639). Nachahmungspoetik und Lebenswelt, eds. Thomas Borgstedt and Walter Schmitz, 99-111. Berlin: de Gruyter.

Open Access Dieses Kapitel wird unter der Creative Commons Namensnennung 4.0 International Lizenz (http://creativecommons.org/licenses/by/4.0/deed.de) veröffentlicht, welche die Nutzung, Vervielfältigung, Bearbeitung, Verbreitung und Wiedergabe in jeglichem Medium und Format erlaubt, sofern Sie den/die ursprünglichen Autor(en) und die Quelle ordnungsgemäß nennen, einen Link zur Creative Commons Lizenz beifügen und angeben, ob Änderungen vorgenommen wurden.

Die in diesem Kapitel enthaltenen Bilder und sonstiges Drittmaterial unterliegen ebenfalls der genannten Creative Commons Lizenz, sofern sich aus der Abbildungslegende nichts anderes ergibt. Sofern das betreffende Material nicht unter der genannten Creative Commons Lizenz steht und die betreffende Handlung nicht nach gesetzlichen Vorschriften erlaubt ist, ist für die oben aufgeführten Weiterverwendungen des Materials die Einwilligung des jeweiligen Rechteinhabers einzuholen. 